\title{
TRENDS IN THE REGIONAL DEVELOPMENT OF BULGARIA
}

\author{
K. Petrov* \\ Department of Regional Development, Faculty of Management and Administration, \\ University of National and World Economy /UNWE/, Sofia, Bulgaria
}

\begin{abstract}
The report examines the socio-economic condition of the Republic of Bulgaria. Some sectors of the Bulgarian economy have been analysed, taking into account their regional peculiarities and revealed serious structural weaknesses. The problem of the effectiveness of the country's financial management was also highlighted, reflecting the dependence on the country's external financing. Another major drawback in the economic development of the country is the state of the transport infrastructure and the maximum utilization of its potential, which inevitably affects the regional integration and local socio-economic development. The report shows the evolution of understandings for rural regions in Bulgaria. They are unified by the area in which they develop - rural regions. They offer opportunities for rest and recovering in environment which is absolutely opposite to the one in their urban and industrial area. In this scope are examined the economic structure of regional development and rural areas in these territories, territorial differences (variety) in the change of employment and unemployment, the role of the demographic situation as a factor in the sustainable development.
\end{abstract}

Key words: economic, regional, integration, reforms, rural regions, rural area

\section{INTRODUCTION}

It was only at the turn of the century that a dramatic change in Bulgarian regional policy occurred. With the dynamic generated by the strengthening of Bulgaria's European perspective the first Regional Development Act was adopted in 1999 and, with it, a new approach to regional policy emerged, with the introduction of important changes in the regional administrative structure, the institutions of regional policy, and the planning of regional interventions. The institutional changes of the 1999 Act also allowed a more integrated policy approach to emerge, and policy emphasis to shift from ad hoc redistribution to enhancing administrative capacities at the regional and local levels. Following, the first integrated national regional programs were developed, initiating the first Operational Program for Regional

*Correspondence to: Kamen PETROV, Vice-Dean in Faculty of Management and Administration, University of National and World Economy, Department of Regional Development UNWE Sofia 1700 Sofia, Student Town, Sofia, Bulgaria, kpetrov@unwe.bg.petrovk@abv.bg
Development. Taking into account the problems of regional development at the national level do not find their irreversibility and consistency. This creates some difficulties in formulating regional development policies and especially in properly defining the priorities of individual regions. After 2007, Bulgaria became a full member of the European Union, which brought to the fore the need to adapt our regional policy to that of the Union. So, it is clear from the review of the development of regional policy in Bulgaria that this can be rather easily divided into four sub-periods: the late central planning period, where some territorial policies were incorporated in the wider planning of sectoral and industrial policies; the transition period developments were slow and largely dictated by national needs and internal constraints; the accession period, where the role of the EU became more central and policy design and implementation started becoming 'Europeanized' and the post-accession period, where regional policy obtains a clear European form and structure. Even though the legislative framework of Bulgaria's regional 
PETROV K.

policy is harmonized with the Europe's twelve years after the country became an EU member, it hasn't shown a big progress in reaching even the EU average levels. Overall, then, even at this period of strong policy development, policy design and implementation was problematic (1). Some elements of over-commitment to EU-like structures (e.g., the design of policies at the NUTS-2 level), combined with a notably thick and complex institutional architecture, poor national finances to support an effective regional policy, and an emphasis on national growth over the aim of tackling disparities, meant that regional policy failed to address the main regional problems of the country, particularly those relating to backwardness, polarization, and spatial un-connectedness. Owing to such developments Bulgaria's regional and spatial problems exhibited a combination of characteristics of polarization, peripheral backwardness, and spatial unconnectedness and localized (sub-regional) inequality. These characteristics are rather clearly depicted in the spatial patterns of inequality in terms of regional incomes in the country (4).

\section{METHODS AND RESULTS \\ Municipalities in Bulgaria}

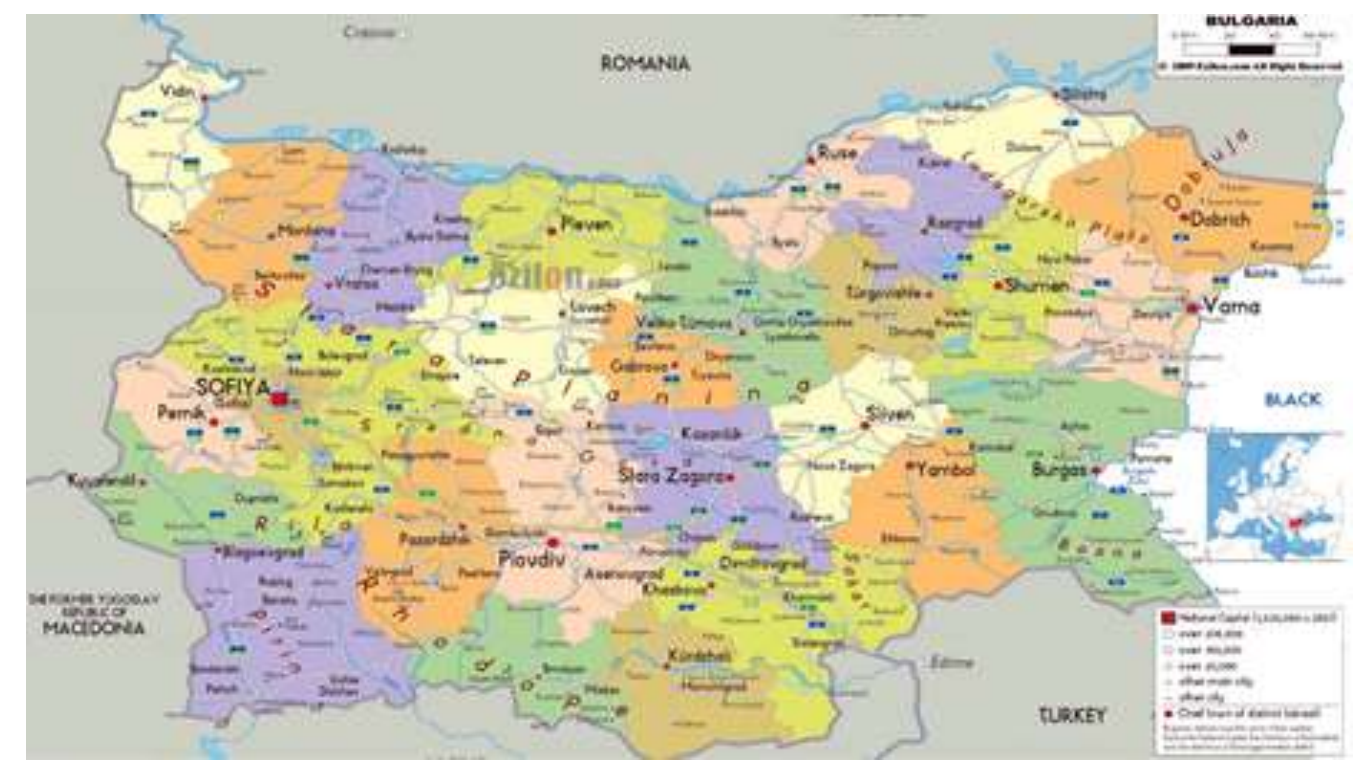

Figure 1. The administrative-territorial structure of the municipalities in Bulgaria Source: NSI (Bulgaria)

\section{The need for territorial and spatial} development measures for settlements.

Territorial development is a multifaceted complex activity aimed at establishing rules and dependencies in organizing environmental protection. Its evolution is part of the biological and social development of every individual. This environment is both a boundary and a link between society and nature. The structure of the territory creates conditions and different rules (including legal ones) are formulated about it, because it is a reflection of both human beings - as a higher thinking being and as a biological species that lives in a socially organized system. The identification of problems with territorial division in the modern state is linked to the process of zoning or territorial division. Territorial division is often linked to the optimal functioning of the socio-economic system in the individual country. Socioeconomic territorial system means economic and socially efficient combinations of interrelated elements of society, purposeful functioning of a particular territory as units of public / in that direction and territorial division of labor and integration of labor (3). Main elements of the socio-economic territorial systems an object of material production and that of non-production sphere them with demographic resources. The economic system is made up of people and institutions, including their attitude to production resources, such as through ownership. The monitoring of the development of a settlement network is a recognized need, both in its past development, for the identification of past processes and problems that have arisen, as well as for its 
PETROV K.

future development and the creation of forecasts using socio-economic development. The settlement network is the created structure of settlements connected with functional, spatial and virtual connections of different intensity between settlements. The study of settlements and their links has always been a key point in all survey studies (2). The stabilization and improvement of the functional hierarchical system of settlements as polycentric and its relatively uniform location throughout the country with a view to acquiring a sustainable and open character is an open problem to overcome. The presentation of the problem central - peripheral territories is one of the main ones in regional policy.

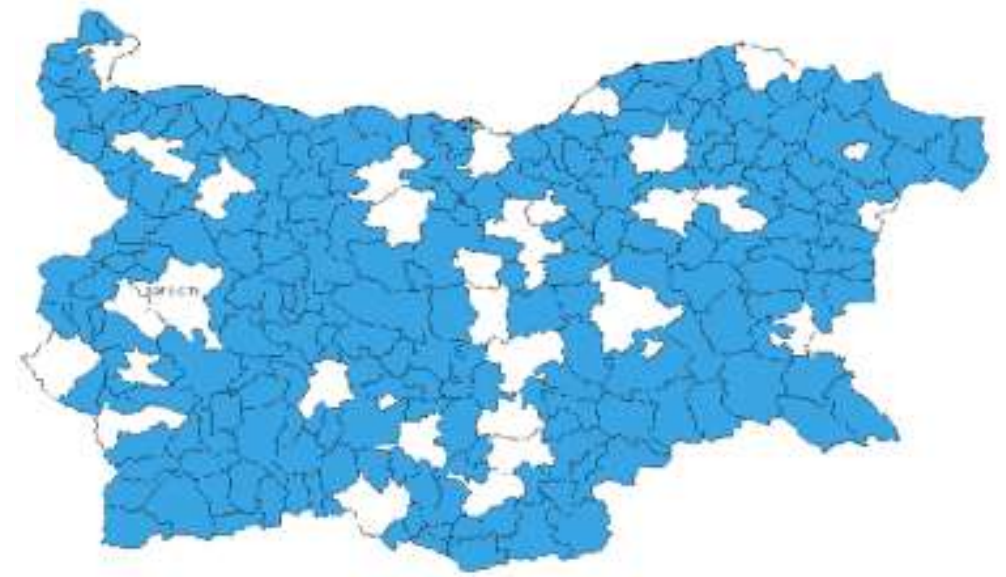

Figure 2. Rural areas in Bulgaria LAU 1 level (geographical scale 1: 1000000) Source: National concept spatial development (2013-2025)

The study of these regional structures through the municipal territorial unit is another important point in regionalism. The municipality is seen as a system that needs to be in a balanced and sustainable state in order to overcome the imbalances of socio-economic development and territorial aspect. By its nature, regional policy is defined as a complex policy which, through the totality of economic, legislative, administrative actions of state and local governments, aims accelerating regional economic growth and overcoming regional disparities development (5). The integrated regional policies are identified as an appropriate mechanism for the development of urban areas, which is why they are supported by a number of Community initiatives: URBAN (1994-2006), URBACT (20072013), Leipzig Charter sustainable European cities (2007) and more. Furthermore, there was low absorption of the EC OP Competitiveness funding ( $€ 1,162$ million), the main source of public funds available for upgrading and modernizing Bulgaria's economy over the 2007-2013 cycle. Until 2021 are opened by the projects under the Operational Program "Regions for Growth" 2014-2020. Through under the Operational Program over 400 infrastructure projects will be implemented, including the major projects of the municipalities of Stolichna, Plovdiv, Varna, Bourgas, Rousse, Stara Zagora and Pleven.
They are for improving the urban environment, transport and road infrastructure. This makes strengthening urban policies in the The EU is one of the main policy objectives after 2021 . Reversing this trend will require a shift in approach and philosophy. Cities are places where many are concentrated challenges, present and future, and are key locations for making Europe's economies stronger, more environmentally and socially engaged. There are groups of conditions that affect territorial planning. First of all, these are natural and geographical factors. The most important is relief. According to the experts in Bulgaria there is an optimal distribution of the territory. The low, hilly and mountainous terrain are almost evenly distributed. The average altitude of $470 \mathrm{~m}$ is also optimal. Mineral resources, water resources, historical factors and the level of development of science and technology are important for the development of the territory (6). The territorial arrangement is subject to certain principles. These are the basic principles that are relevant for all aspects of territorial organization: the principle of democracy, of complexity, of the contradiction between state, municipal and personal interests, of the combination of sectoral and territorial interests, of balance. Ensuring the resilience of the settlement network and building a quality settlement environment, guaranteeing favorable socio-economic and 
PETROV K.

environmental development, is a priority task for the integrated regional development policies and territorial structure and is the

object of the model of the territorial-urban structure of the country and planning regions.

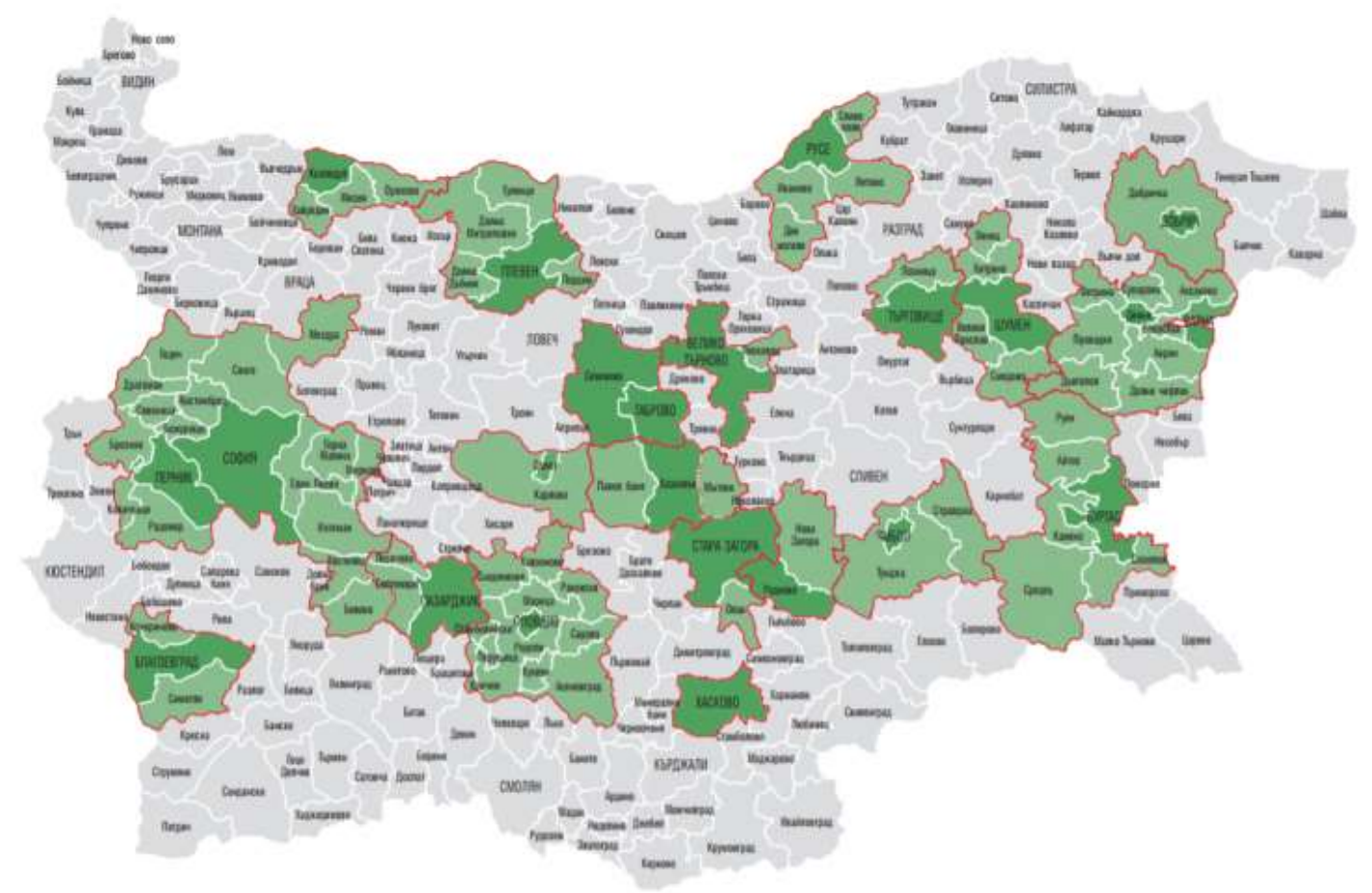

Figure 3. Division of municipalities by economic, spatial and territorial development Source: NSI (Bulgaria)

\section{Connection of regional development and rural development in Bulgaria.}

The careful focus on regional development brings to the fore its dichotomy. It is related to the formation of two fields for regional impact. These are the urbanized territories and their adjacent areas on the one hand and on the other the rural areas and the carrying out of agricultural activity in them. In Bulgaria, the implementation of regional policy is a complex process that combines the concentration of efforts by the state to support individual industries (7). However, this approach is partially successful because it does not in practice set out the general objectives of regional development for both urban areas and rural areas. In practice, the deficit in terms of setting common territorial objectives related to the population, settlements and the regional economy in territorial terms leads to emerging regional imbalances. In this respect, the rural areas in Bulgaria are most affected and in a difficult economic situation. In the rural areas of the country there is a deficit from the implementation of effective regional policies. This deficiency of regional policy is of course important on theoretical grounds, given the fact that persistent regional imbalances raise issues not only of economic cohesion and social justice, but also of economic efficiency. Substantial and persistent income and unemployment differentials lead to inflationary pressures for the national economy, as upward price movements in the better-off areas are not counter-balanced by deflationary movements in poorer areas. In general, negative socioeconomic processes are observed in the rural areas of Bulgaria. A shrinking and aging population makes obsolete entire layers of the public service infrastructure - lack of young families means lack of children, lack of children makes obsolete kindergartens, schools and community centres. The closing of schools cuts down jobs for teachers and pediatricians, reduces the workload for dentists and diminishes the use of public and private transport, etc. The impacts from the negative socio-economic and demographic trends are reinforced by the trends in agriculture. First of all, Bulgarian agriculture is functioning significantly below its potential, and at present the country is not selfsufficient in almost any of agriculture product, except for the output of grain and oil-bearing industrial crops, where huge surpluses are regularly observed each year. Besides these efficiency considerations, however, in the context of transition the deficiency of regional policy is particularly important due to one of the 'stylized' 
characteristics of the very transition process, namely the fast and stark widening of regional disparities. The rural areas of the country are rapidly losing their labour force, a fact which impedes the utilization of the potential for economic growth in these areas. The knowledge, skills and abilities of the remaining workforce are decreasing. This process is associated with increasing poverty and decreasing purchasing power in rural areas; which leads to a shrinking demand for, and consumption of goods and services; this makes it even harder for the emergence of new businesses - especially in the tertiary sectors of the economy(8). At hindsight, this made a poor situation worse, arguably contributing to the widening of regional disparities and intensifying problems of asymmetry and backwardness for the less developed areas of the country. Rural areas include most of the EU and nearly half of its population. They provide living space and a means of livelihood for millions of people, much of the food, a number of basic raw materials for the industry as well as recreation space, attractive to visitors. The specific character of rural areas within the EU is determined by their social and cultural identity. Every rural area has a unique geographical location, natural resources, history, ethnic composition of the population, religion and traditions, urban network, economic potential. Every rural area is unique in terms of its geographical location, its natural resources, history, ethnic composition of the population, religion and traditions, urban network, economic potential.

Agriculture is an integral part of the economy - it provides the raw materials to be processed and marketed by various value adding chains in the food industry, but also in various other sectors of the light processing industry cosmetics, pharmacy, textiles, hide and leather production, and in turn is used by clothing and shoemaking industries, etc. While larger urban centers can have the capacity to export goods and services not originating or associated with agriculture, forestry and fishery, smaller rural settlements rarely can do so, because they lack the similar concentration of human capital with diverse knowledge and skills. In the case of rural economies, money from exported raw materials is indeed like the influx of oxygen rich blood to the limbs of a body. The greater the quality of the local produce and the degree of added value, the greater the amount of
PETROV K.

sustainability entering the local socioeconomic system. The delayed development of agriculture in economic sense and according to thenumber of employed was identified as a basic tendency in rural regions development. The level of social dialogue in the agroeconomy can and should be improved given the importance of the sector for the light processing industry and the rural economy in general.

\section{New projects to improve regional development in Bulgaria.}

In territorial termsp Bulgaria may accept the project approach as efforts focused on building large infrastructure enable regional connectivity in North-South direction, and then to focus towards the regional economy development. This can be done by attracting strategic investors or creating conditions to support the production specific for the regions of the country, this specific approach is crucial for the regional development of Bulgaria. Largely in this profile should start from the Danube coast. Looking more globally Bulgarian Danube coast as an important part of the national territory is necessary to bring out the specific features of this coastal territory associated with its geopolitical and geoeconomic dimensions. Development of the route of the 7th Euro corridor in the region is the most important element for its infrastructure development and its functional linkage of Silistra, Ruse and Svishtov Danube ports. Their technical and technological modernization will allow developing intelligent transport systems in the whole region and also that of the Atlantic destinations from the Rhine-Main-Danube to the Black Sea and further to Caucasus-Central Asia and the Far East to the Middle East and North Africa. An important component of its infrastructure development is building a parallel (in along the Danube river) a high-speed road, very important for further economic linking the Danube riparian areas of the district. For their project, cold the EU Danube Strategy important is participation of Danubian municipalities of the region in its implementation. Needed is also to create a legal opportunity for the development private ports in the Black Sea and the Danube. Together with a simplification of procedures in the construction of new ports, expanding the existing ones, and the abolition of the institution of the right to use water body. The main problem standing in front of a building 
PETROV K.

new or expanding existing public transport ports and those mentioned in 107-109 LSSIWPRB (marinas, fishing ports and special purpose) is rooted in the status of the seabed (also the bed and a flood plain of the River Danube). This determines the inability for the construction and expansion of the port, which is not owned by the state. Since the business has clearly manifested the desire to overcome existing legal obstacle currently is absolute, for construction of new or expansion of existing ports - municipal and private property. For example, is necessary to build new grain port on the Danube River at Aydemir near Silistra. The size of the port terminal should be at least 4 berths and storage with a total capacity of 68000 tons. We need the government to commit to building a new inlet and path asphalting of part of the existing to the future port terminal. The planned turnover volume of grain is 150,000 tons after the start of operation at full capacity of the base. In these amounts will be $70 \%$ cereals and $30 \%$ oilseeds. Upon adoption of any legislative approach to overcome the problem is to find a balance between intense to public and the private investors. Possibility, people who wills to build a port with a property which is between more owners is more than acceptable for the safety and security of shipping and the macroeconomic logic. To overcome this problem, the State should at some point to withdraw the rights to build new ports, which would mean adopting approach "first in time is stronger in law." This approach is fully in line fair competition and do not fit fully into the modern community. Another possibility to overcome that disadvantage is the creation on objective criteria, with the result that it can be determined which owners to grant rights and which - not. The State can hardly control the process through detailed development plan for violations macroeconomic logic can hardly become a reason to give up coordination of the plan (8). Strategic importance may have Northeastern Bulgaria. First it has to be renovated electrification and double the railway line Ruse-Varna. Samuel-line Silistra is seeking an opportunity to build speed road in the direction of Silistra-Shumen-Rishki PassKarnobat. An important condition regional development is the certification of airports in Targovishte and Silistra in international terminals, for cargo and low-cost civil flights. Thus Bulgarian State must prepare the new Economic Development Plan for the period 2020- 2030 whit a special attention to Dobrich,
Silistra and Shumen regions, in it quickly the sustained economic growth should be imitate (3). It is also necessary to pay special attention to North coast. Emerging new challenges, especially considering the emerging new "North-South" pattern of regional relations mainly in direction requires the search for news creative solutions for regional development (4). Recently becomes urgent need of question is building new port terminals hot of feasibility of the implementation of the second industrial port in the Northern Black sea coast. Localization this port may be mostly by Shabla, but this area lies within the "Natura 2000"zone. However, this can create conditions to examination of be realized natural extension of the European Transport Corridor №8 Varna should be finished soon to Constanza and eventually to Ukraine and Moldova. On the Romanian side is good to finish the highway Constanta-Varna on the Bulgarian one to create a link from the Hemus highway after Aksakovo over Balchik towards Romanian border and to connect to Romanian howay in the border. The realization of this project is necessary to strengthen transport traffic on the 8th Euro corridors within the country through the port Constanta Bulgaria to be integrated into this new geo-economic area. For similar project and its realization is appropriate adoption of new spatial development solutions (5). This means that apart from the construction of express road is necessary to modernize railway links to direction Dobrich-Kardam-Constanta mostly by their electrification reaching a maximum speed of 140-160 km. The significant role in the regional development of this region may have Rousse, due to its strong gravitational potential of Ruse and its implications to Razgrad, Svishtov, Levski, Biala and other municipalities. This would give Ruse need a real gravitational potential to influence the dynamics and direction of movement labour resources (labour force), the direction of the dominant vector of both cultural and educational ties, and those under the administrative, legal, communal services to the population in North Central Region Planning such overall strengthening the role of Ruse is logical and reasoned. Ruse also has crucial update on the construction of the route of the 9th Euro corridors in the country. In this respect, the update of the master plan of Ruse contents construction of new railway track to Danube Bridge I, which is displaced by urban area also, planning a new bridge to replace the 
PETROV K.

old one in 15-20 years. Then it is important that building of the speed road Ruse - Gorna Oryahovitsa on a new route, in my opinion outside urban areas and settlements. In the new conditions, is necessary for Gorna Oryahovitsa to become a major transport hub in northern Bulgaria where you will meet themselves "Hemus" highway, alternative paths to Pleven and the new express road in the direction of upper Gorna Oryahovitsa-LyaskovetzSheremetya-Malak Chiflik-Debelec to be carried traffic along Veliko Tarnovo, whit the most important turns detour of Gabrovo and specially road tunnel under the Shipka Pass. In practice, infrastructure development of Central Bulgaria especially the routes of the European transport corridors, will directly and indirectly influence the whole northern Bulgaria, and later it will came direct relation for the technical modernization of ports Somovit, Belene, road Nikopol-Pleven-Lovech-Troyan and multi highway tunnel Troyan-Hr. Pole. Thus, it will give a new horizon of transport and urban axis through extra modernization and construction of high-speed road RuseByala-Pleven-Jablanica. In practice, economic specialization of the central parts of Northern Bulgaria region is strengthening the industry: engineering, chemical, food and light one. Their technological and territorial restructuring nowadays take place and has prospects for future development of dis territory (4). The sustainable development of the processing industry is possible, according to production traditions of the population in the period of economic transition, a developed resource base and availability of markets for their produce. It is also important to bring rural problems to the fore. In Northern Bulgaria there was a clear specialization and zoning in the vegetable production (near Danube's areas and along the rivers Yantra, Ruse Lom, Osam, Vit), grain cultivation (northern and central areas, Danube plain, Ludogorie), and that of perennial crops and potatoes, and also the environmental pastoralism fore and Stara Planina.

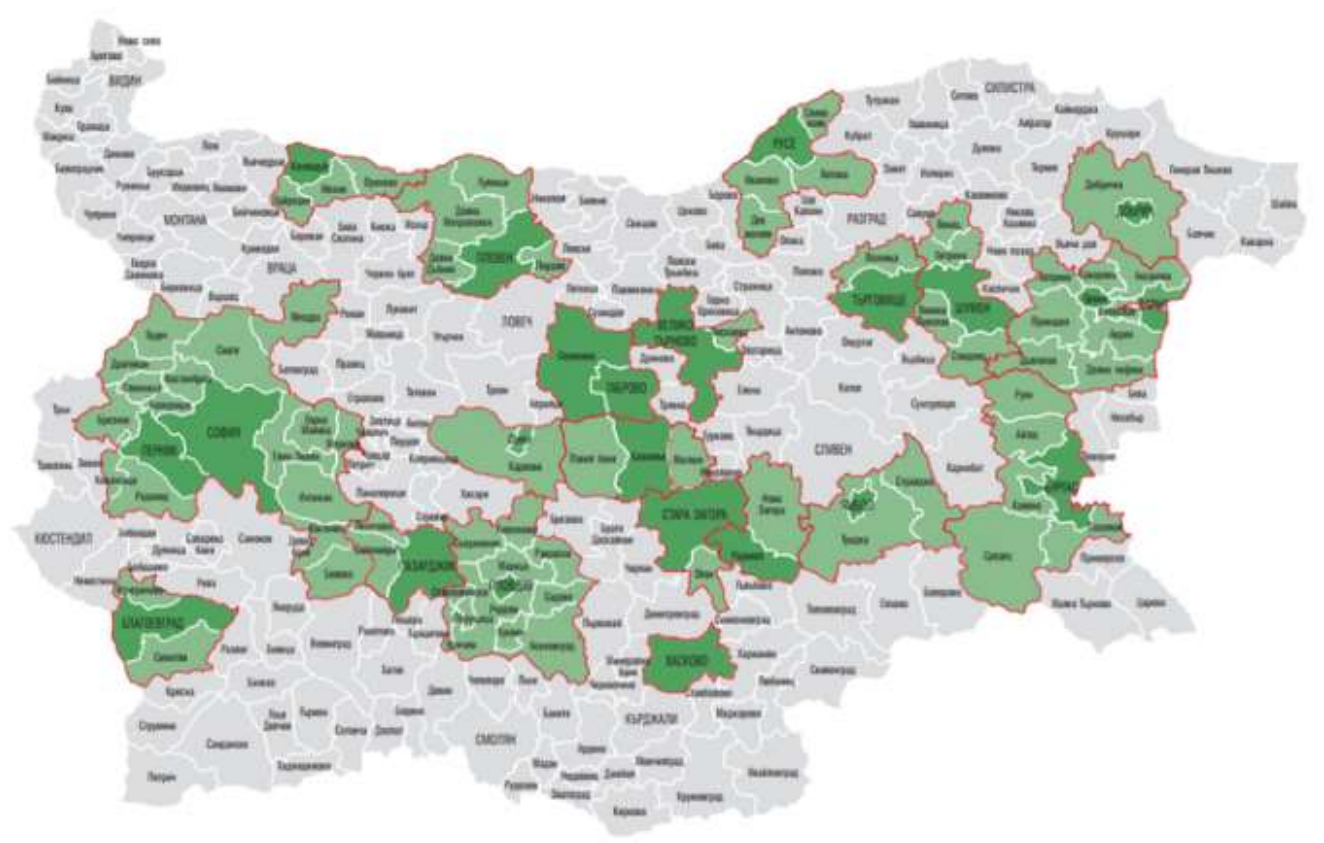

Figure 4. The separate regional economic centers of Bulgaria. Source: NSI (Bulgaria)

In South Bulgaria it is necessary to pay more attention to the main roads improving. The road between highway was built south in the foothills of the Balkan Mountains to connect Sofia and Burgas - the shortest link of those two cities of a great economic importance for the development of infrastructure, industry and agriculture, in the settlements of the whole region. The transition between Sofia Plain and Zlatitsa-Pirdop valley is done with the mountain pass through the Galabets saddle.
For its construction were used favorable Balkan valleys between the Balkan and Central Forest. In this direction it is necessary to create conditions for economic interaction on both sides of the Balkan Mountains mainly through the establishment of join factories and companies, as well as putting the competitive advantages of settlements in both parts of this range. At national level changes in the Law on Regional Development shut contain a special program for the development of the Balkan 
PETROV K.

region. The municipalities of Berkovitsa, Tryavna Kazanlak, Pavel Banya, Elena, Kotel, Sungurlare, Troyan, Karlovo will be influenced on their regional development and measuring the priorities for their regional economy. In this direction we can go towards the development of regional industrial clusters to consolidate further economic territory of the Balkan region. This means that the use of its cultural, historical and natural potential for the development of regional economy creates opportunities for investment and construction of facilities that may have significant potential, which is a prerequisite for sustainable development of regional economy. Thus, for the regional economic development in Southern Bulgaria it turned out to be important to attract investments, especially in the industry, which created conditions for its stabilization and development. The effect of the construction of the Maritza and Trakia highways was important, but a number of other infrastructure projects were not implemented. There are still deficits in terms of the development of alternative traffic routes and the improvement of regional accessibility in a number of territories in Southern Bulgaria (5). Another major problem remains the deteriorating demographic situation in southern Bulgaria, as well as environmental challenges. The appearance of the coronavirus also slowed down the modernization of the Bulgarian regions. Regarding regional development, the implementation of projects such as the Black Sea Highway, the doubling of the PlovdivBurgas railway, the construction of a two-lane tunnel under Shipka, the widening of the Stara Planina passes, as well as the improvement of water supply and sewerage in most settlements in Bulgaria.

In recent years, the areas around the capital and respectively the South-West planning region have developed the most. In practice, there are a number of problems to solve that can have a negative impact on the regional development of the country. Focus is also toward the most developed area of Bulgarian Southwest Region, where the only developed area is that of Sofia as whole the once Blagoevgrad, Kyustendil and Pernik are worsen or stalled. At the same time the analysis of socio-economic indicators for the implementation of regional development plans indicate that Southern Regions need also serious economic change.
The tendency to increase the share of the urban population leads to the transformation of cities into economic and administrative centers, as well as to places where the main functions of the human life cycle - habitation, work, recreation, servicing and related technical infrastructure - are prioritized. This defines the great importance of cities in terms of the development of the national territory as a whole, but at the same time causes the concentration of a number of problems related to the use of their territory - overbuilding, environmental pollution, scarcity of green spaces, lack of places for parking, providing certain comfort and habitation, providing social infrastructure facilities, as well as building and maintaining networks and technical infrastructure facilities. All of this brings to the fore the issues of sustainable urbanization, and in particular of sustainable urban management. In recent years, in Bulgaria, as a result of increased anthropogenic impact, some of the large and medium-sized cities are expanding their territorial scope beyond their construction boundaries, exporting their economic and social functions to a wider territory, covering the lands of several settlements. In this way, to a certain extent, the planned space of the city almost coincides with the planning of the territory of urban land. We distinguish several types of proximity in a spatial aspect: cognitive, organizational, social, institutional, and geographic (2).

Market growth, market size and access to international and regional markets are among the most important factors that can influence the choice of location for investment by companies, followed by the quality of the business environment, including the availability of skilled labor, suppliers and adequate infrastructure. Embedding Bulgarian regions in the economy at the international level cannot be done by delivering products at competitive prices without sufficient and good quality electricity, telecommunications and transport networks and without the presence of other key factors such as mass access to drinking water. This means that regional development of Bulgarian territory must its focused and adequacy, and leads to improved well-being of our environment. So that the participation of large corporations in concessions such as "build - acquisition service" or management contracts to become real and to create conditions for permanent 
PETROV K.

presence of economically active persons in the Bulgarian regions to be develop branch and specialized Bulgarian regional economy. The support for all productive business and/or for improvement of public facilities should be accompanied with a horizontal requirement that the businesses or public services achieve greater energy efficiency or become energy independent after the support is over. This will be a great contribution to the competitiveness of businesses in the medium and long term, but will also open and preserve green jobs associated with the planning, construction and upkeep of the respective facilities (6). Territorial coherence policies should take into account and stimulate the potential for spatial interaction. For this purpose, it is necessary to build institutional frameworks at the regional level to coordinate effectively the process of regional development.

\section{CONCLUSION}

The aim of conducting regional policy is related to finding opportunities for purposeful impact on the territory through tools and activities that should highlight the regional development as a national priority of the contemporary modern state. Practically regional development means a balance between the priorities of municipalities districts and planning regions and search for the most important issues for them solving related to national priorities and understandings of development regions as separate territorial communities. Regarding globalization of trade in agricultural goods, and climate change - it appears that Bulgaria still has to prepare for climate related challenges, as its irrigation system and vulnerability to droughts and floods continues to be high. As the role of the external factor has been dramatically transformed over the years, Bulgaria may have to look into its own domestic limitations and constraints to find the appropriate institutional and socio-political configurations that will facilitate the harmonious development of the national component of regional policy and the efficient operation of the chosen regional interventions, so as to effectively tackle the continuing problems of polarisation, backwardness and unconnectedness that characterise the Bulgarian sub-national economic space. Regional and sub-regional inequalities is one of the main problems for regional and national development in Bulgaria appears to be related to the very weak and heterogeneous spatial connectivity of its local economies. The overall prospects for sustainable socio-economic development and regional development in application view of the supranational European policies in the next programming period where the goals and objectives of period 2021- 2027 can be achieved only in strong and competitive economies able to support national investments in research and constant innovation, as well as in the knowledge and practical skills of the local people.

\section{REFERENCES}

1. Boschma, R. and K. Frenken (2015), Evolutionary Economic Geography. Papers in Evolutionary Economic Geography \# 15.18.

2. Bachev, H., Ivanov, B., Toteva D., \& Sokolova, E. (2017) Agrarian sustainability in Bulgaria - economic, socialand ecological aspects. Bulgarian Journal of Agricultural Science, 23(4), 519-525.

3. Vladev, I. Trends in spatial distribution and population density of the following Bulgarian socio-economic territorial systems: Shumen, Novi pazar, Kaspichan, and Veliki Preslav.//Proceedings of the XIII Conference „Natural Sciences'2015“

4. Capello R., P. Nijkamp (Eds.), 2009, Handbook of regional growth and development theories, Edward Elgar

5. Marinov, P., (2018) Natural Resource Potential in the Rural Areas of the South Central Region, Plovdiv, Fast Print Books, pp. 103-106

6. Dimitrov, P., M. Stoyanova. (2016). Longrun forecasting of the SPA and wellness tourism development in Bulgaria.

7. Patarchanov,P, Em Patarchanova, V. Zarkov,. The need for a new logic in the regionalization of the national space. Proceedings of the International scientific and practical conference "Bulgaria of regions'2018". University of agribusiness and rural development, Plovdiv $19-21$ October, 2018. 91-104

8. Patarchanova, Em. (2012) Socio Economic Patterns and Trends in Rural Development in EU, Journal of Settlements and Spatial Planning, vol. 3, No. 2, 2012, Cluj University Press, Cluj-Napoca, Romania, p. 151-155 